\title{
Treatment of acute gonococcal urethritis in Bangkok, Thailand
}

\author{
STUART T. BROWN AND TALMAGE MCMINN \\ From the Department of Hospital Clinics, U.S. Army Hospital, and the Department of Bacteriology, \\ SEATO Medical Research Laboratory, Bangkok, Thailand
}

In most areas of the world, Neisseria gonorrhoeae has become increasingly less sensitive to antimicrobials, both in vitro and in vivo, as discussed by Willcox (1970), Martin, Lester, Price, and Schmale (1970), and Sparling (1972). Because of this trend, the doses of penicillin necessary to obtain satisfactory cure rates have greatly increased. The current recommendation by the Venereal Diseases Branch of the U.S. Public Health Service (1972) includes a penicillin injection volume which may be limiting because of local pain.

Throughout the Far East, the frequency of gonococcal strains with reduced antimicrobial sensitivity has been high for many years and has tended to increase, as Willcox (1970) and Reyn (1969) have reported. Thus, the problems experienced elsewhere in establishing adequate treatment regimens for gonorrhoea have been even greater in South-East Asia. We report here the studies conducted to establish effective treatment schedules for gonorrhoea in Bangkok, Thailand. These studies may be relevant to other areas in the Far East and to certain groups in the United States.

\section{Patients and methods}

From December, 1971, to February, 1973, 628 American servicemen with gonococcal urethritis were treated with the current treatment schedule.

\section{DIAGNOSIS}

The diagnosis was based upon the demonstration of Gramnegative intracellular diplococci in a smear or the isolation of $N$. gonorrhoeae from urethral scrapings obtained by inserting a bacteriological loop 1 to $2 \mathrm{~cm}$. into the urethra.

Received for publication November 5, 1973

Presented in part at the Third International Symposium on Venereal Disease, New Orleans, Louisiana, June 1-2, 1973

Address for reprints: Stuart T. Brown, M.D., Seattle-King County Health Department, Venereal Disease Clinic, Seattle, Washington 98104

The views of the authors do not purport to reflect the position of the Department of the Army or the Department of Defence

\section{CLINICAL EVALUATION}

Patients with symptoms of urethritis were interviewed and examined, and smears of urethral material were taken. After April, 1972, urethral cultures were obtained in most cases. If Gram-negative intracellular diplococci were not demonstrated, the examination was repeated after the patient had held his urine overnight. When gonococcal infection was diagnosed, contact interviewing was done and the patient was treated. If gonococcal infection was not established and the patient had a heavy urethral discharge or had recently taken antibiotics, the examination was performed a third time. If the gonococcus was not demonstrated, the patients were treated with tetracycline for non-specific urethritis. Treatment failures on this drug were further evaluated for trichomonal urethritis, prostatitis, or other conditions.

\section{LABORATORY METHODS}

Smears were Gram-stained and examined in the hospital laboratory. The material for culture was plated on both Thayer-Martin and 10 per cent. blood agar plates maintained at room temperature. With less than a 2-hr delay, these plates were placed in candle-extinction jars and incubated at $37^{\circ} \mathrm{C}$. The plates were examined for growth after 24 and $48 \mathrm{hrs}$. Selected colonies were tested with oxidase reagent and stained by Gram's method.

Isolates presumed to be Neisseria gonorrhoeae were subcultured on Thayer-Martin medium. Standard sugar fermentation tests were done, using a cystine trypticase agar base. The organism was considered to be $N$. gonorrhoeae if it was an oxidase-positive, Gram-negative dipplococcus, which fermented 1 per cent. glucose, but failed to ferment 1 per cent. sucrose or lactose. Minimum inhibitory concentrations (MIC) of penicillin were determined using Mueller-Hinton plates containing $0.0,0.05$, $0 \cdot 1,0 \cdot 2,0 \cdot 4,0 \cdot 6,0 \cdot 8,1 \cdot 0,1 \cdot 2,1 \cdot 4,1 \cdot 6,1 \cdot 8$, and $2 \cdot 0$ units per ml. penicillin. Controls employing staphylococcal reference strains and $N$. gonorrhoeae reference strains from the WHO Reference Laboratory (Dr. A. Reyn) were included.

\section{TREATMENT}

Five penicillin treatment schedules were used over the 14 months in six consecutive, non-random treatment periods, and kanamycin was used for patients who were allergic to penicillin (Table I). 
TABLE I Treatment schedules for gonococcal urethritis

\begin{tabular}{|c|c|c|}
\hline $\begin{array}{l}\text { Schedule } \\
\text { number }\end{array}$ & Treatment $t^{\mathrm{a}}$ & Treatment period \\
\hline 1 & $\begin{array}{l}1 \mathrm{~g} \text {. probenecid and } 2.4 \mathrm{~m} . \mathrm{u} \text {. pro pen } \\
\text { (one intramuscular site) }\end{array}$ & Dec. 71-Jan. 72 \\
\hline 2 & $\begin{array}{l}1 \text { g. probenecid and } 4.8 \mathrm{~m} . \mathrm{u} \text {. pro pen } \\
\text { (two intramuscular sites) }\end{array}$ & Tan. 72-Mar. 72 \\
\hline 3 & $\begin{array}{l}2 \mathrm{~g} \text {. probenecid and } 4.8 \mathrm{~m} . \mathrm{u} \text {. pro pen } \\
\text { (two intramuscular sites) }\end{array}$ & Apr. 72-Jun. 72 \\
\hline 4 & $\begin{array}{l}2 \mathrm{~g} \text {. probenecid and } 3.5 \mathrm{~g} \text {. ampicillin } \\
\text { (orally) }\end{array}$ & Jul. 72-Aug. 72 \\
\hline 5 & $\begin{array}{l}2 \text { g. probenecid and } 4.8 \mathrm{~m} . \mathrm{u} \text {. pro pen } \\
\text { (two intramuscular sites) }\end{array}$ & Sep. $72-$ Oct. 72 \\
\hline 6 & $\begin{array}{l}2 \mathrm{~g} \text {. probenecid and } 5.0 \mathrm{~m} . \mathrm{u} \text {. pen } \mathrm{G} \\
\text { (one intramuscular site) }\end{array}$ & Nov. 72-Jan. 73 \\
\hline 7 & $\begin{array}{l}2 \text { g. kanamycin } \\
\text { (one intramuscular site) }\end{array}$ & Apr. 72-Jan. 73 \\
\hline
\end{tabular}

aProbenecid was given 10 to $15 \mathrm{~min}$. before ampicillin ingestion and 45 to $60 \mathrm{~min}$. before penicillin injection

m.u. =million units; pro pen $=$ aqueous procaine penicillin $G$;

pen $\mathrm{G}=$ sodium penicillin $\mathrm{G}$ dissolved in $8 \mathrm{ml} .1$ per cent. xylocaine

Patients who had recurrent disease received either $2 \mathrm{~g}$. kanamycin or $4.8 \mathrm{~m} . \mathrm{u}$. procaine penicillin plus $2 \mathrm{~g}$. probenecid; after June, 1972, the latter combination was used for those unable to return for follow-up.

\section{FOLLOW-UP}

Most patients were instructed to attend again after 1 week. They were then examined a minimum of $4 \mathrm{hrs}$ after last passing urine and in most cases after holding urine overnight. Smears of urethral scrapings were taken from all patients, and cultures of urethral scrapings were done at the follow-up examination for all patients seen after April, 1972. Two-glass urine specimens were acidified and examined grossly for haze, heavy threads, or clumps.

Patients were considered to have been followed if they returned within 3 weeks of therapy. All patients who had $N$. gonorrhoeae demonstrated at the follow-up visit were defined as having recurrent disease. This group thus includes patients that others would classify as having either a re-infection or a relapse.

\section{Results}

\section{LABORATORY FINDINGS}

Both smears and cultures were done in 433 cases. Both were positive in 405 cases (94 per cent.); smears were positive and cultures negative in twenty cases and cultures positive and smears negative in eight. At least two of the twenty patients with negative cultures had taken inadequate antimicrobial therapy (tetracyline) within the $12 \mathrm{hrs}$ preceding our tests. It is estimated that 3 to 5 per cent. of patients with both smears and cultures positive had positive smears only on the second or third visit to the clinic, while cultures from all visits were positive. Mimea were isolated on non-selective media in eighteen cases, but all patients with positive smears and Mimea on culture also had $N$. gonorrhoeae isolated.

MIC determinations for penicillin were done on 362 of the isolates (Figure) and ranged from 0.05 to $1.8 \mathrm{u} . / \mathrm{ml}$. 192 isolates ( 53 per cent.) were considered highly insensitive to penicillin, with an MIC of $0.6 \mathrm{u} . / \mathrm{ml}$. or greater, while 322 (89 per cent.) had an MIC of $0.1 \mathrm{u} . / \mathrm{ml}$. or greater.

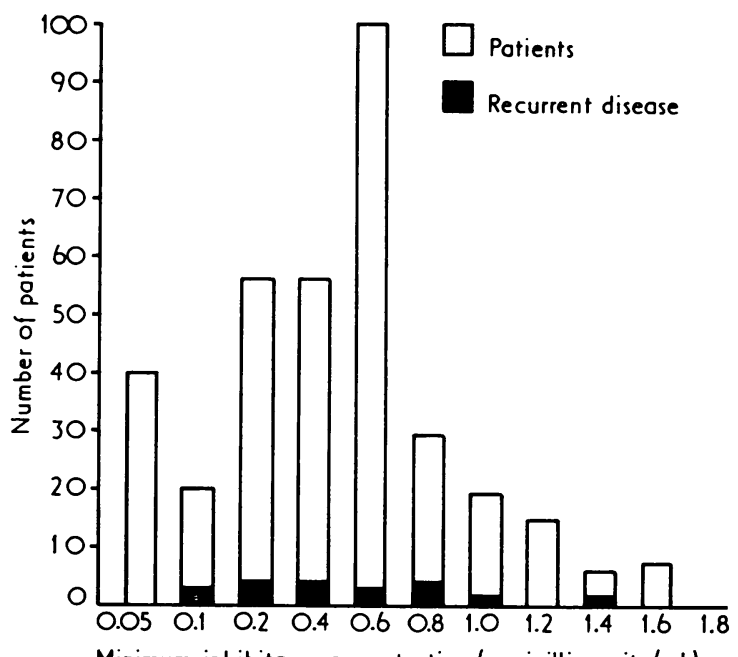

FIGURE Penicillin sensitivity of $\mathrm{N}$. gonorrhoeae isolates in Bangkok, Thailand, April, 1972, to fanuary, 1973

\section{CLINICAL FINDINGS}

The results with various treatments are presented in Table II. Although the diagnosis of recurrence after Schedules 1 and 2 was based solely on the use of smears of urethral scrapings, the recurrence rate was 50 and 31 per cent. respectively. $2 \mathrm{~g}$. probenecid

TABLE II Results of treatment

\begin{tabular}{|c|c|c|c|c|c|c|}
\hline \multirow[b]{2}{*}{$\begin{array}{l}\text { Schedule } \\
\text { no. }\end{array}$} & \multirow[b]{2}{*}{ Dosage } & \multirow[b]{2}{*}{$\begin{array}{l}\text { No. of } \\
\text { patients treated }\end{array}$} & \multicolumn{2}{|c|}{ Patients followed } & \multicolumn{2}{|c|}{ Recurrent disease } \\
\hline & & & No. & Per cent. & No. & $\begin{array}{l}\text { Percentage of } \\
\text { those followed }\end{array}$ \\
\hline $\begin{array}{l}1 \\
2 \\
3 \\
4 \\
5 \\
6 \\
7\end{array}$ & $\begin{array}{l}1 \mathrm{~g} . \text { probenecid }+2.4 \mathrm{~m} . \mathrm{u} \text {. pro pen } \\
1 \mathrm{~g} . \text { probenecid }+4.8 \mathrm{~m} . \mathrm{u} \text {. pro pen } \\
2 \mathrm{~g} \text {. probenecid }+4.8 \mathrm{~m} \text {.u. pro pen } \\
2 \mathrm{~g} . \text { probenecid }+3.5 \mathrm{~g} \text {. ampicillin } \\
2 \mathrm{~g} \text {. probenecid }+4.8 \mathrm{~m} . \mathrm{u} \text {. pro pen } \\
2 \mathrm{~g} \text {. probenecid }+5.0 \mathrm{~m} . \mathrm{u} \text {. pen } \mathrm{G} \\
2 \mathrm{~g} \text {. kanamycin }\end{array}$ & $\begin{array}{r}24 \\
73 \\
136 \\
98 \\
136 \\
134 \\
27\end{array}$ & $\begin{array}{l}14 \\
45 \\
89 \\
69 \\
80 \\
83 \\
18\end{array}$ & $\begin{array}{l}58 \\
62 \\
65 \\
70 \\
59 \\
62 \\
67\end{array}$ & $\begin{array}{r}7 \\
14 \\
5 \\
5 \\
6 \\
7 \\
1\end{array}$ & $\begin{array}{l}50 \\
31 \cdot 1 \\
5 \cdot 6 \\
7 \cdot 2 \\
7 \cdot 5 \\
8 \cdot 4 \\
5 \cdot 5\end{array}$ \\
\hline
\end{tabular}


plus $4.8 \mathrm{~m}$.u. procaine penicillin were used nearly 10 weeks apart in Schedules 3 and 5, but had similar recurrence rates of 5.6 and 7.5 per cent. The combined recurrence rate for this therapy was 6.5 per cent. (eleven recurrences in 169 patients followed). The use of $3.5 \mathrm{~g}$. ampicillin plus $2 \mathrm{~g}$. probenecid (Schedule 4) was associated with recurrent disease in five of 69 patients followed (7.2 per cent.). Nongonococcal infections in this group were, however, severe (vide infra). Recurrence after $2 \mathrm{~g}$. probenecid plus 5 m.u. sodium penicillin $G$ (Schedule 6) occurred in seven of 83 patients followed (8.4 per cent.). After 2 g. kanamycin, used to treat patients allergic to penicillin, only one recurrence was observed in the eighteen patients followed. Throughout the study, the percentage of patients who were followed remained relatively constant, ranging from 58 to 70 per cent. in the various treatment groups (Table II).

\section{COMPLICATIONS}

One patient treated by Schedule 1 developed acute epididymo-orchitis in the week after therapy. Cultures were not available during this time, but the gonococcus could not be demonstrated in smears from urethral scrapings. Post-gonococcal urethritis (PGU) with abnormal 'two-glass' urine tests and of mild clinical severity occurred in each group, but among those given ampicillin nearly 25 per cent. of the PGU was associated with severe symptoms and signs resembling gonococcal urethritis. In all these patients two or three cultures for $N$. gonorrhoeae were submitted during follow-up and were negative before therapy for PGU.

Complications associated with the injectable drugs were limited to moderate local pain of a transient nature. No sciatic nerve involvement, abscess formation, or other severe local reactions were noted. None of the drugs appeared to have a significantly greater incidence of painful reactions. No severe psychotic reactions were noted with the procaine penicillin regimes and accelerated allergic reactions were not observed.

The ingestion of a large pill mass, either probenecid or ampicillin, was associated with mild, acute, upper gastrointestinal complaints in a few patients, but was not associated with later upper or lower gastrointestinal problems. Among the 601 patients taking probenecid, one developed an acute urticarial reaction 45 minutes after ingestion of the tablets. $\mathrm{He}$ had no associated wheezing or oedema. The reaction was relieved with an antihistamine and subsequent antibiotic therapy did not exacerbate the condition.

\section{Discussion}

\section{LABORATORY OBSERVATIONS}

Other workers have been able to isolate $N$. gonorrhoeae in 91 to 99 per cent. of the cases with positive smears (Phillips, Humphrey, Middleton, and Nicol, 1971; Holmes, Johnson, and Floyd, 1967; Maurer and Schneider, 1969; Ashamalla, Walters, and Crahan, 1966; Eriksson, 1970; Tiedemann, Hackney, and Price, 1965). Our ability to isolate the organism in 94 per cent. of cases suggests that the technical difficulties with smears listed by Willcox (1970) were avoided in these studies. Although only 2 per cent. of our cases were identified by cultures alone, this figure is estimated at 5 to 7 per cent. if the patients had been seen on only one occasion.

The number of strains of gonococci with reduced sensitivity to penicillin in vitro in this unselected group of isolates was high, 89 per cent. having an MIC of $0.1 \mathrm{u} . / \mathrm{ml}$. or greater, more than 50 per cent. $0.6 \mathrm{u} / \mathrm{ml}$. or greater, and 12 per cent. $1 \mathrm{u} . / \mathrm{ml}$. or greater. Suvanamalik (1971) reported that 37 per cent. of unselected strains from elsewhere in Bangkok had an MIC of $0.5 \mathrm{u} / \mathrm{ml}$. or greater. More recent studies have documented an increase in the degree of insensitivity of strains at this laboratory (personal communication with Dr. S. Suvanamalik). These do not approach the degree of insensitivity found by Reyn (1969), but the strains she reported on may have been from 'problem cases' in Thailand.

\section{CLINICAL OBSERVATIONS}

The use of $2.4 \mathrm{~m} . \mathrm{u}$. procaine penicillin $1 \mathrm{hr}$ after $1 \mathrm{~g}$. probenecid was based on the success reported by Holmes and others (1967), Holmes, Johnson, Stewart, and Kvale (1968), and Keyes, Halverson, and Clarke (1969) in other areas with 'resistant' gonorrhoea. This was quickly demonstrated to be an unsuccessful regime, recurrent disease being noted in 50 per cent. of cases. Doubling the dose of procaine penicillin decreased the recurrence rate, but only to 31 per cent.

Because of local pain, $4.8 \mathrm{~m} . \mathrm{u}$. procaine penicillin seemed to be near the maximum single-session dose. Meads, Knight, and Izlar (1951) and Frisk, Diding, and Wallmark (1952) have reported that the enhancement of serum penicillin levels by probenecid is dose-related up to 4 g., and Boger and Strickland (1955) suggested that toxicity as a result of shortterm administration of this drug was minimal. Recently, Cornelius, Schroeter, Lester, and Martin (1971) and the British Medical Fournal (1968) (quoting unpublished observations of F. R. Curtis) reported that the use of $2 \mathrm{~g}$. probenecid in combination with large doses of procaine penicillin caused 
no serious side-effects. We therefore increased the dose of probenecid to $2 \mathrm{~g}$. and gave $4.8 \mathrm{~m}$.u. procaine penicillin $1 \mathrm{hr}$ later. A recurrence rate of less than 7 per cent. was found with this combination, and $2 \mathrm{~g}$. probenecid was therefore used in all subsequent penicillin trials.

Oral therapy is painless and is possibly associated with fewer severe allergic reactions than parenteral administration. A single-session oral dose of ampicillin plus probenecid had been successfully used in cases of gonorrhoea in the Philippines by Kvale, Keyes, Johnson, and Holmes (1971), so this method was included in our studies. Although we were unable to demonstrate gonococcal recurrence in more than five out of 69 patients, the frequency and severity of apparent post-gonococcal urethritis that we observed precludes further use of this combination in our clinic.

Olsen and Lomholt (1969) used a combination of $1 \mathrm{~g}$. probenecid and 5.0 m.u. sodium penicillin G, and reported no significant side-effects during 4 years of use. Morton and Onn (1971) reported that this combination was successful in Singapore, where insensitivity in vitro is as common as in Bangkok.

Acceptance of this single injection by patients was also excellent. Our results with this combination were not significantly different from those for Schedules 3, 4,5 , or 7 , although 8.4 per cent. of patients had recurrent disease.

Both the studies in vitro of Suvanamalik (1971) and unpublished clinical studies in Bangkok suggested that tetracycline was not the best therapy here. We therefore used kanamycin for the initial therapy of patients allergic to penicillin. Although the number treated was small, this seemed to be a satisfactory drug. (Spectinomycin was not available during most of this time.)

Since we were unable to differentiate reliably between patients with re-infection and those with relapse, both groups were considered under the heading 'recurrence'. Patients with recurrent disease were seen an average of 10.7 days after therapy and seven of 24 patients in Groups 3 to 7 returned during the third week of follow-up. The MIC values for those with recurrences were not significantly higher than for the entire group. This suggests that a large number of the cases included in our recurrence group were re-infected, and would explain our inability to achieve more than a 92 to 94 per cent. cure rate with these treatment schedules. It is interesting to note that Holmes and others (1968) inferred a 6 per cent. re-infection rate in patients followed over a 3-week period.

The failure of 35 per cent. of the patients to return for follow-up may be in part related to our practice of planning return visits 1 week after therapy. Since the completion of this study, we have asked patients to return 2 to 4 days after therapy, and there has been an increase in the follow-up rate to nearly 90 per cent.

\section{Conclusions}

Factors which influence gonococcal disease are unique and changing in every area; therefore studies to establish optimal therapies should be a part of the activities of each venereal disease clinic. Doubling the dose of probenecid seemed to improve the efficacy of procaine penicillin. Although the treatment groups and their evaluation and follow-up were felt to be similar, similarity cannot be assured without a randomized prospective trial. If such a study substantiated this impression, further increases in antimicrobial insensitivity of gonococci might still be met within single-session penicillin therapy. Of greater long-term importance will be better disease control, better understanding of the mechanisms of antimicrobial insensitivity, and a lessening of the pressures which favour the development of antimicrobial insensitivity of $N$. gonorrhoeae.

\section{Summary}

The results of studies in 628 men with acute gonococcal urethritis attending a clinic in Bankgok, Thailand, are presented. The minimum inhibitory concentration of penicillin was $\geqq 0.1$ unit per $\mathrm{ml}$. for 89 per cent. of the isolates of Neisseria gonorrhoeae, confirming their high frequency of reduced sensitivity in this area. Therapy with four out of six different treatment schedules successfully cleared the infection in more than 92 per cent. of cases. Increasing the dose of probenecid which preceded $4 \cdot 8 \mathrm{~m}$.u. procaine penicillin from 1 to $2 \mathrm{~g}$. was associated with a decrease in disease recurrence from 31 to $5 \cdot 6$ per cent. The need for studies of therapeutic efficacy is emphasized, particularly in areas where less sensitive organisms are common.

Without the support of Col. John P. Canby, M.C., and the advice of Dr. R. S. Morton, these studies would not have been possible. The medical auxiliaries who assisted us include Thomas Gerrity, Henry George, and William Brooks.

\section{References}

Ashamalla, G., Walters, N. R., and Crahan, M. (1966) f. Amer. med. Ass., 195, 1115 
Boger, W. P., and Strickiand, S. C. (1955) Arch. intern. Med., 95, 83

Brit. med. F. (1968) 3, 391 'Treatment of gonorrhoea today'

Cornelius, C. E. III, Schroeter, A. L., Lester, A., and MARTIN, J. E. (1971) Brit. F. vener. Dis., 47, 359

ERIKsson, G. (1970) Acta derm.-venereol. (Stockh.), 50, 451

Frisk, A. R., Diding, N., and Wallmark, G. (1952) Scand. F. clin. Lab. Invest., 4, 83

Holmes, K. K., Johnson, D. W., and Floyd, T. M. (1967) f. Amer. med. Ass., 202, 461

,-- STewart, S., and Kvale, P. A. (1968) Milit. Med., 133, 642

Keyes, T. F., Halverston, C. W., and Clarke, E. J. Jr. (1969) F. Amer. med. Ass., 210, 857

Kvale, P. A., KeYes, T. F., Johnson, D. W., and HOLMES, K. K. (1971) Ibid., 215, 1449

Martin, J. E. JR., Lester, A., Price, E. V., and Schmale, J. D. (1970) f. infect Dis., 122, 459

MAURER, L. H., and SCHNEIDER, T. J. (1969) f. Amer. med. Ass., 207, 946

MEADS, M., KNIGHT, V. H., and IzLAR, H. L., JR. (1951) Sth. med. F., 44, 297

MoRTON, R. S., and ONN, L. Y. (1971) Singapore med. F., 12, 86

Olsen, G. A., and Lomholt, G. (1969) Brit. F. vener. Dis., 45, 144

Phillips, I., Humphrey, D., Middleton, A., and Nicol, C. S. (1971) Ibid., 48, 287

ReYN, A. (1969) Bull. Wld Hlth Org., 40, 257

Sparling, P. F. (1972) Med. Clin. N. Amer., 56, no. 5, p. 1133
Suvanamalik, S. (1971) 'Sensitivity of N. gonorrhoeae to penicillin and other antibiotics'. Presented at the WHO Regional Symposium on Venereal Diseases, Bangkok, Thailand, 14-17 December, 1971

Tirdemann, J. H., Hackney, J. F., and Price, E. V. (1965) f. Amer. med. Ass., 191, 89

Venereal Diseases Branch, U.S. Bureau of State Services, Center for Disease Control (1972) Ann. intern. Med., 76, 991

WILlcox, R. R. (1970) Brit. F. vener. Dis., 46, 217

Traitement de l'urétrite gonococcique aigüe à Bangkok

SOMMAIRE

On présente le résultat d'études effectuées chez 628 hommes atteints de gonococcie urétrale aigüe consultant dans une clinique de Bangkok, Thailande. La concentration inhibitrice minimale de pénicilline fut $\geqslant 0,1$ unité $/ \mathrm{ml}$ pour 89 pour cent des isolements de Neisseria gonorrhoeae; ceci confirmant la haute fréquence d'une sensibilité réduite dans la région.

L'infection guérit dans plus de 92 pour cent des cas traités par 4 des 6 différents schémas thérapeutiques utilisés. En augmentant la dose de probénécide de 1 à $2 \mathrm{~g}$ avant l'injection de 4,8 m.u. de pénicilline-procaine, on assista à une diminution des rechutes de 31 à 5,6 pour cent. On souligne la nécessité d'études sur l'efficacité thérapeutique, particulièrement dans les régions où l'on trouve communément des organismes moins sensibles. 